\title{
Chapter 6 \\ The CGIAR (Consultative Group on \\ International Agricultural Research) System
}

\author{
William Dar
}

It is an honour to represent the Consultative Group on International Agricultural Research (CGIAR) in this major global conference. The CGIAR would like to express its gratitude to Tunisia for hosting this conference on behalf of the world community.

We are also grateful to UNESCO for leading the planning and organization of this major event, along with the Sahara and Sahel Observatory, as well as to the many institutions involved in the organizing activities and those who have contributed to funding conference. Finally, I wish to thank all of you who have come here to share your knowledge and expertise.

The CGIAR fully shares the world's vision of a better future for the drylands, safe from the scourge of desertification, to be achieved in accordance with the United Nations Convention to Combat Desertification. As a non-profit international organization, we in the CGIAR work in close partnership with national and regional research organizations across the developing world.

We appreciate that this conference focuses on the role of science in combating desertification. It is too easy for misunderstandings about desertification to grow and become 'conventional wisdom'. When that happens, we exhaust our energy working on the wrong problems. We also confuse the public and lose their support. The role of science is to help us to find the facts and stick to them, to go after the real problems, and to target the right interventions.

We also have to be on guard against the impressions about drylands that we get from the media. Disaster, suffering and crisis make headlines. But they do not tell the whole story.

Mr. Chairman, we believe that managing misery is not enough. There is quiet progress in many dryland areas, driven by the wisdom and sense of responsibility that the people living there hold for their lands. Like us, they too dream of a better future. If we focus only on the chaos and suffering, we think too small. We have to think of the possibilities and potentials, and they are great.

Director-General of ICRISAT (International Crops Research Institute for the Semi-Arid Tropics), India 
This is where science and research come in. Research is powerful because it creates new possibilities that can change the equation of development. My organization, the CGIAR, focuses on stimulating a global network of research organizations.

Together with our partners, we have developed a number of innovations that build livelihoods while protecting the drylands. Here are just a few:

- Leading-edge technologies to map and measure land degradation.

- Ways to protect dryland plants and animals.

- More drought-resistant varieties of staple food crops.

- More productive livestock and fish breeds, and ways to manage them.

- Soil-enriching technologies that the poor can afford.

- New farming systems that integrate trees, crops, livestock and fish, reducing risk through diversity.

- Higher-value agricultural products to raise incomes in drylands.

- Ways to care better for rangelands, forests and watersheds in the drylands.

- An understanding of the decision-making processes of poor land users and how those decisions affect desertification.

- Ways to bring communities and governments together to manage lands better in order to combat desertification.

- Policy options for more sustainable dryland management.

The CGIAR consists of 15 centres that work in hundreds of countries across the developing world. Their work to combat desertification is united under the banner of a programme called 'Oasis'. We chose the name Oasis to reflect our belief that a much brighter future lies ahead for the drylands through the concerted efforts of all of us in partnership with land users. By combining forces, our partnerships can take the holistic approach that the problem demands.

Mr. Chairman and distinguished colleagues, we hope that this conference carries forward the message that all is not doom and gloom in the drylands, that, on the contrary, the possibilities are enormous if science is harnessed, through research, to change the equation fundamentally. Let us go beyond managing misery to a future where we build livelihoods while saving lands.

We look forward to learning from all of you - and to making new friends in this wonderful country.

Thank you. 